\title{
THE VIEWS OF ERASMUS OF ROTTERDAM AND HIS POLISH FOLLOWERS ON WAR AGAINST THE TURKS
}

I $\mathrm{n}$ the first three decades of the 16th century, Erasmus of Rotterdam (1466-1536) became a "one-man-institution", and, at the same time, despite all his love for his native Netherlands - 'a citizen of Europe'. I am aware of the 'ahistoricity' of these declarations; nevertheless, I believe they provide an accurate description of the phenomenon we are dealing with in the case of this figure. It might be more accurate to say, however, that he was a citizen of the Respublica Litteraria, for whom ethnicity, nationality, political or state affiliations were of little importance, and fade into the distance, in view of his immersion in the world of classical philology and culture. ${ }^{1)}$

In the present text, I am going, first of all, to analyse Erasmus's opinion on 'the Turkish issue' and his position on the struggle against the Ottoman Empire. The other subject of interest for me, is Erasmus's impact on Polish humanists and poets in this respect. This issue, examined from many points of view, has already been investigated by many mainly Polish (but not exclusively) historians, literary scholars and philologists. The question has been studied by Wacława Szelińska, ${ }^{2)}$ Zofia Szmydtowa, ${ }^{3)}$ Maria Cytowska, ${ }^{4)}$

\footnotetext{
1) Domański (1995: 177-191).

2) Szelińska (1990).

3) Szmydtowa (1972: passim, especially 181-284); Szmydtowa (1964: 68-100).

4) Cytowska (1992: CVIII-CXXII); Cytowska (1973: LIV-LVIII); Cytowska (1980: 7-28).
} 
Janusz Tazbir, ${ }^{5)}$ Henryk Barycz, ${ }^{6)}$ Leszek Hajdukiewicz, ${ }^{7)}$ Stanisław Łempicki, ${ }^{8)}$ Claude Backvis ${ }^{9)}$ and finally Piotr Tafiłowski. ${ }^{10)}$ Erasmus's influence on the anti-Trinitarian writers has been analysed by Konrad Górski ${ }^{11}$.

There is obviously no room here for an examination of the huge legacy of Erasmus. ${ }^{12)}$ I can only use the findings of students of the issue and some selected examples.

Erasmus supported the unification of Europe, and, in the second stage, the conclusion of an anti-Turkish alliance by Christian rulers. However, according to his idea, it would not have an offensive character, nor would its objective have been to attack and drive out the Ottoman army from Europe. He recognized only the right to defend oneself, while the establishment of Christian unity and cessation of conflicts between rulers would constitute the best guarantee for peace, and also protection against attack by the Ottoman state. His concepts were therefore consistent with Martin Luther's position.

Thus, Erasmus's goal became to convince all rulers in Europe that the Turks were the common enemy of Christian monarchs and that one could oppose them only by cooperation, by bridging the divisions between Protestants and Catholics. All the European strategists seemed to be fully aware of this, although it was likewise clear that it was not possible to attain this ideal.

When writing to Polish dignitaries concerning the need for the unity of the Christian world and for the establishment of peace in Europe, as well as the necessity of reaching an agreement between Christian rulers in the face of the Turkish threat, Erasmus stated: "It is destined that the Turk will suppress the revolts of sects, violence of monks, and impudence of those who, in the name of the Pope, do what they like. I would rather avoid so cruel a doctor!". ${ }^{13)}$ In another letter, written to King Sigismund I the Old, (Zygmunt Stary) from Basel, on May 15, 1527, he said: "Plato regarded as civil war the struggle waged by Greeks against Greeks. Yet a Christian is bonded with

\footnotetext{
5) Tazbir (1983: 29-37).

6) Barycz (1953: LXXI-XCIX).

7) Hajdukiewicz (1971: 69-73).

8) Łempicki (1952: 123-1343); Kopera (1897); Cytowska (1965).

9) Backvis (1975: 560-587).

10) Tafiłowski (2006: 91-94).

11) Górski (1949).

12) Allen (1906-1958); Le Clerc (1703-1706).

13) A letter to Krzysztof Szydłowiecki, Cytowska (1965: 174).
} 
a Christian more closely than a citizen with a citizen, even closer than brother with brother! And now this discord between monarchs opens the way to the Turks. First they captured Rhodes, recently they also invaded Hungary. Too lucky was that cruel conquering drive! And the Turks will wedge in even deeper between us unless we, reconciled, defy them together with our shields". ${ }^{14)}$ Erasmus's diagnosis is therefore that Turks are a bitter remedy for the disorder in Europe, the scourge of God and a warning that wars should be stopped and efforts be made to unite Christendom, and that they are a mirror in which the Christians should see their misdeeds.

The above mentioned letter to King Sigismund I, was soon published in Hieronymus Vietor's printing house in Krakow (Epistola ad inclytum Sigismundum Regem Poloniae). The editor of the volume, which also contained 20 poems by humanists associated with the University of Krakow (Georgius Logus, who taught in Košice and in Prešov, Georgius Werner, Jan Lang of Silesia, and an Englishman Leonard Coxe), was the later cardinal and champion of the Counter-Reformation, Stanislaus Hosius (Stanisław Hozjusz), who dedicated this work to the Krakow Bishop, Piotr Tomicki. On the last recto page, Erasmus's epigram and portrait appears, on the verso page, Piotr Tomicki's epigram and coast of arms.

Similarly, in another, earlier letter to Abbot Anton von Bergen, which is one of the first anti-war works in world literature, Erasmus emphasized what, he believed, the causes of war were: "ambitions of rulers, a craving for conquests and spoils, anger, and revenge; he [also] demonstrated that every war brings only destruction and impoverishment to the winner and the defeated; he condemned its atrocities". ${ }^{15}$

In The Praise of Folly, which was basically meant as an ironic treatise; all facetious notes disappear when war is mentioned. "Moria speaks of war and participants in it with outrage and aversion. She states that war is so inhuman that it contaminates all customs, so unjust that the worst brigands usually wage it best. Such an extreme generalization is matched elsewhere by the enumeration of those who eagerly join the army, namely all kinds of society outcasts. An absolute opponent of war, not even hiding his reservations about the Crusades, Erasmus spoke against war in The Praise of Folly with all severity, quite openly, without oscillating between seriousness and comedy”. ${ }^{16)}$

\footnotetext{
14) Letter to Sigismund I, Cytowska (1965: 69).

15) Barycz (1953: XL).

16) Szmydtowa (1972: 18-19).
} 
Erasmus's pacifism manifested itself most explicitly in the Complaint of Peace, ${ }^{17)}$ Charon $^{18)}$ or Education of a Christian Prince, and also in adages (War is sweet to those who do not know $\left.i t^{199}\right)$. Especially worth noting is the fact that this attitude was not characterized by the features of Christian exclusivity, and that Erasmus's love of peace and fierce aversion to war also applied to the Muslims - the 'unbelievers'. This world view is reflected inter alia in his praise of King Sigismund I, who deserved it because of his policy of peace: "To you, more important is the peace of the Commonwealth [of Poland] and saving Christian blood than even so large dominions conquered by arms. Nor do you care about the opinion of the common people. That famous writer [Plutarch] spoke finely on the subject, saying, it is truly royal and a feature of every loftiest mind to bear accusations when one acts in a noble way. You also did not reject the possibility of negotiations with the Turks (...)" ${ }^{20)}$ Concord is always the best and Muslim believers should not be converted by fire and sword but only by means of good example. For, "it is not the befitting principle that if we will kill as many Turks as we can that we can call ourselves good Christians, but the one that we will save as many as we can; not the principle that we will send many thousands of heathens to hell, but the one that we will convert as many heathens as we can". ${ }^{21)}$ The University of Krakow professor, Pawel Włodkowic, had advocated the same prohibition towards conversion by fire and sword a hundred years earlier.

In Erasmus's letter to Paul Wolz, an introduction to The Handbook of the Christian Soldier, where problems of this kind are examined, the discussion exhibits his characteristic, philological traits. Erasmus associates Truth with simplicity of language - regarding scholastic intricacies, the more they complicate a problem, the further they depart from the truth. If the Turks were to read the works of the scholastics, "abounding in difficulties and insolvable complicacies concerning instances, formalities, quiddities and relations", they would never believe evangelical teachings. How much Erasmus disliked the style of those writings is shown by what he wrote, putting himself in the Turks' position: "What will they think if they see that the matter is so difficult

\footnotetext{
17) Cytowska (1992: 209-234).

18) Cytowska (1992: 241-250).

19) Cytowska (1973: 287-343).

20) Letter to Sigismund I, Cytowska (1965: 71).

21) Domański (1965:269). Interestingly enough, in this edition the entry "Turek, Turcy" [Turk, Turks] was included in the index of persons at the end of the book.
} 
that it was never decided what words should be used to speak of Christ, just as though you were dealing with a bothersome demon whom you invoke to your undoing if you use wrong verbal formulas, rather than with the most kind-hearted saviour who wants nothing from us but living a pure and honest life." ${ }^{22)}$ Without entering into a theological dispute, we should say again that, to Erasmus, the Turks are a mirror in which, this time, the Christians should look at themselves in order to purify the language and style of speaking of the doctrine and Christ, because: "the Turks and all those pagan hordes of true barbarians claim the glory of professing the true religion and laugh at Christian superstition.”. ${ }^{23)}$

Rather than threaten the Turks with military power, or impress them with wealth, Erasmus advocated converting them to Christianity through moral example. As, "a supporter of Socrates' view that virtue is inherently linked with knowledge, that one must know how to act to act well, he found it right to influence the Turks by means of the printed word. On many occasions, he repeatedly pointed out the need to limit the dogmatic side and emphasize moral force in teaching the Gospel. In the mission aimed at winning over Islamic believers to the Christian community he found it advisable first to hand them a short outline of all Christian philosophy drawn up by several most competent commentators, in a simple and at once scholarly way, brief but also lucid.". ${ }^{24)}$

Erasmus returned to this theme several times. In The Handbook of the Christian Soldier he wrote that, "the Christian should cover some with his love because they are good and others to make them good. He must not hate any man, at any rate no more than a reliable doctor hates the patient: he (the Christian) should only be an enemy of sins. The more serious the illness, the greater care will be offered by pure love. 'This is an adulterer, a sacrilegist, a Turk.' Let him (the Christian) curse the adulterer but not a man, let him despise the sacrilegist but not a man; let him kill a Turk, not a man. He must make an effort so that a sacrilegist who made himself a sacrilegist die, but a man, whom God created, is saved." ${ }^{25)}$ In another place he wrote: "We curse the Turks and it appears to us that we are good Christians thanks to that. However, to God it is through these deeds that we become more disgusting

22) Domański (1965: 267-268); Szmydtowa (1972: 80).

23) Barycz (1953: 83-84).

24) Domański (1965: 270); Szmydtowa (1972: 90-91).

25) Domański (1965: 181). 
than the Turks. What if the ancient prophets who preached the Gospel had treated us as we treat the Turks today? It is after all only thanks to the gentleness and kindness of the prophets that we became Christians. Help the Turks to turn from the unbelievers into the faithful followers of the Christian religion" ${ }^{26)}$

In 1530, after the siege of Vienna laid by the Turks the previous year, Erasmus wrote a minor treatise in the form of a commentary to Psalm XXVIII, Ultissima consultatio de bello Turcis inferendo. In it, he briefly described the might of the Turks, including specific items of advice and information concerning the Turks, at the same time calling for the unity of Europe. Nevertheless, it does not contain, which his contemporary public opinion expected, a direct call to war. Erasmus, "although he should have encouraged armed action against the Turks, speaks with full courage: Not every war against the Turks is right and just". ${ }^{27)}$

The indecisive attitude of this humanist annoyed Johan Huizinga: "If he sometimes does interfere in current affairs, he is only moralizing using generalities, without emphasis; his advice whether to declare a war on the Turks (in March 1530) is expressed in the form of explanations to Psalm XXVIII and is so vague that at the end he himself anticipates the reader's impression, who may perhaps shout: Say it explicitly then, do you think this war should be fought or not?" ${ }^{28)}$

Erasmus himself wrote: "As far as I am concerned, I am somewhat reserved even about anti-Turkish crusades. Indeed, something is wrong with Christian religion if its integrity depends on such defence only. We will never win good Christians in this way; what the sword gains will also be lost by the sword. We want to convert the Turks. We should not show them only wealth and military might. To the Turks, we should not be Christians only by name. Let them also see the virtues proper to the Christians: immaculacy of life, friendliness and kindness to neighbours, even to enemies, patience in bearing insults, contempt for wealth, fame and vain pleasures of life. Let the Turks hear about this divine teaching to which the Christian's life is accordant. This is the best weapon for defeating the Turks. How often, at present, we, the wicked, are fighting against the wicked. I would put it in one more different

\footnotetext{
26) Miła wojna dla tych, co jej nie znaja, Cytowska (1973: 333).

27) Cytowska (1973: XXVIII).

28) Huizinga (1964: 243).
} 
way, may it prove impudent rather than true. If we remove the sign of the cross from our ranks, it will appear that Turks fight with Turks." ${ }^{29}$

For Erasmus no war is just. He wrote that he preferred a genuine Turk to a false Christian, and that he did not oppose a war against Turkey if attacked first. However, any war in the name of Christ should be waged in His spirit and with humanitarian methods. ${ }^{30}$

As Zofia Szmydtowa emphasizes: "his reserve even towards the crusades did not demonstrate his absolute opposition to armed actions, like in some doctrines regarded as heretical, but his resolute challenge, within the limits admissible by the Church, to the arguments for any war" ${ }^{31)}$ This is a justified reservation because Erasmus was suspected of heresy even by the Church, while he himself thought it fit to defend himself: "If someone points out that it is truly apostolic to win over the Turks to religion by such means as Christ used rather than by weapons, he is immediately suspected of teaching that the Turks should by no means be stopped when they attack the Christians." ${ }^{22}$

Thomas More attacked Martin Luther for his statement that the Turkish invasion was a divine punishment for the sins of the rulers and the people. He mistakenly believed that Luther also claimed that, since it was a divine punishment, it was a sin to fight against the invasion. ${ }^{33)}$ Therefore, Erasmus's pacifism might have incurred more suspicion that he supported the Reformation movement, from which he repeatedly had to distance himself; the phrase "some doctrines" mentioned by Z. Schmydtowa meant simply 'Lutheranism'. The intention of the before mentioned defence might have been personally addressed to More, Erasmus's friend, in whose eyes Erasmus did not want to be regarded as a follower of Luther.

Finally, we should return to the impact of Erasmus's views about war on Polish writers. There are not too many examples because the authors of antiTurkish literature in Poland did not belong to the circle of Erasmians. These were rather two different circles, without much in common. For example, Stanisław Orzechowski, the author of the most famous anti-Turkish speeches, not only did not belong to the circle of Erasmians, but at certain periods was even in great conflict with some of them, for instance with Andrzej Frycz

\footnotetext{
29) Miła wojna dla tych, co jej nie znaja, Cytowska (1973: 332).

30) Adams (1962: 209).

31) Szmydtowa (1972: 89).

32) Domański (1965: 283). On Erasmus’s pacifism see also Adams (1962: passim).

33) Adams (1962: 274-275).
} 
Modrzewski [Andreus Fricius Modrevius] (they fell out with each other after being close friends for twenty years, when Orzechowski unexpectedly turned towards Catholic orthodoxy). In contrast, Modrzewski did not write antiTurkish pieces. In his speeches, he referred to the war against the Ottomans only occasionally, and when he did so, he did not differ too much in his views from Erasmus, calling first of all for unity in all Christendom (this being the central theme of many, and not only his, writings). The same theme appears in Zgoda [Concord] by Jan Kochanowski (another follower of Erasmus, who also did not write anti-Turkish poems).

Nevertheless, Erasmus's influence, as I have emphasized, can be observed in the practice of Polish politics of this age. No calls for war against the Turks were heard, but were rather disregarded. I regard this as being a matter of great importance.

\section{BIBLIOGRAPHY:}

Adams (1962) = Robert P. Adams, The Better Part of Valor. More, Erasmus, Colet and Vives, on Humanism, War and Peace, 1496-1535, Washington 1962.

Allen (1906-1958) = Des. Erasmi Roterodami. Opus Epistolarum, (ed.). P. S. Allen, t. 1-11, Oxford 1906-1958.

Backvis (1975) = Claude Backvis, "Losy Erazma z Rotterdamu w Polsce”, in: Szkice o kulturze staropolskiej, Warszawa 1975.

Barycz (1953) = Henryk Barycz, "Wstęp", in: Erazm z Rotterdamu, Pochwała gtupoty, translated and edited E. Jędrkiewicz, Wrocław 1953.

Cytowska (1965) = Maria Cytowska (translated and edited) Korespondencja Erazma $z$ Rotterdamu z Polakami, Warszawa 1965.

Cytowska (1973) = Maria Cytowska, "Wstęp", in: Erazm z Rotterdamu, Adagia (wybór), (ed.) M. Cytowska, Wrocław 1973.

Cytowska (1980) = Maria Cytowska, Erazmianizm w literaturze polskiej XVI-XVII w., in: Studia porównawcze o literaturze staropolskiej, Wrocław 1980.

Cytowska (1992) = Maria Cytowska, "Wstęp", in: Erazm z Rotterdamu, Wybór pism, translated by M. Cytowska, E. Jędrkiewicz, M. Mejor, selected, introduced and commented on by M. Cytowska, Wrocław-Warszawa-Kraków 1992.

Domański (1965) = Erazm z Rotterdamu, List do Pawła Wolza [in:] Podręcznik żotnierza Chrystusowego, translated by. J. Domański, Introduction by. L. Kołakowski, Warszawa 1965.

Domański (1995) = Juliusz Domański, "La république des lettres Erasmienne", in: Société et Église. Textes et discussions dans les universités d'Europe centrale pendant le moyen âge tardif, Z. Włodek (ed.), Turnhout 1995. 
Górski (1949) = Konrad Górski, Studia nad dziejami polskiej literatury antytrynitarskiej, Kraków 1949.

Hajdukiewicz (1971) = Leszek Hajdukiewicz, "Erazm z Rotterdamu w opinii polskiej XVI-XVII w.", in: Erasmiana Cracoviensia: w 500-lecie urodzin Erazma $z$ Rotterdamu (1469-1536), Zeszyty Naukowe Uniwersytetu fagiellońskiego CCL, Prace Historyczne, no. 33, Kraków 1971.

Huizinga (1964) = Johan Huizinga, Erazm, Warszawa 1964.

Kopera (1897) = Feliks Kopera, Dary $z$ Polski dla Erazma $z$ Rotterdamu, Kraków 1897.

Le Clerc (1703-1706) = Desiderii Erasmi Roterodami, Opera omnia, (ed.) J. Le Clerc, t. 1-10, Lugundi Batavorum 1703-1706, reprinted Hildesheim 1961-1962.

Łempicki (1952) = Stanisław Łempicki, Renesans i humanizm z Polsce: materiaty do studiów, Warszawa 1952.

Szelińska (1990) = Wacława Szelińska, Ksiażka Erazma $z$ Rotterdamu w środowisku krakowskim w XVI wieku, Kraków 1990.

Szmydtowa (1964) = Zofia Szmydtowa, "Erazm z Rotterdamu a Kochanowski", in: same author, Poeci i poetyka, Warszawa 1964.

Szmydtowa (1972) = Zofia Szmydtowa, O Erazmie i Reju, Warszawa 1972.

Tafiłowski (2006) = Piotr Tafiłowski, "Erazm z Rotterdamu a prymas Jan Łaski”, Rocznik Biblioteki Narodowej, 2006: 37-38.

Tazbir (1983) = Janusz Tazbir, "Polska recepcja "Rozmów potocznych" Erazma z Rotterdamu”, Przegląd Humanistyczny, 5 (1983). 